\title{
Effects of stored feed cropping systems and farm size on the profitability of Maine organic dairy farm simulations
}

\author{
A. K. Hoshide, ${ }^{\star} \dagger^{1}$ J. M. Halloran, ${ }^{\star}$ R. J. Kersbergen,‡ T. S. Griffin,§ S. L. DeFauw, ${ }^{\star}$ B. J. LaGasse, ${ }^{\star}$ \\ and S. Jain\# \\ *New England Plant, Soil and Water Laboratory, USDA, Orono, ME 04469 \\ †School of Economics, University of Maine, Orono 04469 \\ fUniversity of Maine Cooperative Extension, Waldo 04915 \\ §Friedman School of Nutrition Science and Policy, Tufts University, Boston, MA 02111 \\ \#Civil and Environmental Engineering, University of Maine, Orono 04469
}

\section{ABSTRACT}

United States organic dairy production has increased to meet the growing demand for organic milk. Despite higher prices received for milk, organic dairy farmers have come under increasing financial stress due to increases in concentrated feed prices over the past few years, which can make up one-third of variable costs. Market demand for milk has also leveled in the last year, resulting in some downward pressure on prices paid to dairy farmers. Organic dairy farmers in the Northeast United States have experimented with growing different forage and grain crops to maximize on-farm production of protein and energy to improve profitability. Three representative organic feed systems were simulated using the integrated farm system model for farms with 30, 120, and 220 milk cows. Increasing intensity of equipment use was represented by organic dairy farms growing only perennial sod (low) to those with corn-based forage systems, which purchase supplemental grain (medium) or which produce and feed soybeans (high). The relative profitability of these 3 organic feed systems was strongly dependent on dairy farm size. From results, we suggest smaller organic dairy farms can be more profitable with perennial sod-based rather than corn-based forage systems due to lower fixed costs from using only equipment associated with perennial forage harvest and storage. The largest farm size was more profitable using a corn-based system due to greater economies of scale for growing soybeans, corn grain, winter cereals, and corn silages. At an intermediate farm size of 120 cows, corn-based forage systems were more profitable if perennial sod was not harvested at optimum quality, corn was grown on better soils, or if milk yield was $10 \%$ higher. Delayed harvest decreased the protein and energy content of perennial sod crops,

Received March 14, 2011.

Accepted July 24, 2011.

${ }^{1}$ Corresponding author: aaron.hoshide@umit.maine.edu requiring more purchased grain to balance the ration and resulting in lower profits. Corn-based systems were less affected by lower perennial forage quality, as corn silage is part of the forage base. Growing on better soils increased corn yields more than perennial forage yields. Large corn-based organic dairy farms that produced and fed soybeans minimized off-farm grain purchases and were the most profitable among large farms. Although perennial sod-based systems purchased more grain, these organic systems were more profitable under timely forage harvest, decreased soil quality, and relatively lower purchased energy prices and higher protein supplement prices.

Key words: dairy, economic, integrated farm system model, organic

\section{INTRODUCTION}

Over the past decade, the demand for organic food has grown rapidly. Sales of organic food increased from $\$ 3.6$ billion in 1997 to $\$ 21.1$ billion in 2008 (Greene et al., 2009), making organically produced foods the fastest growing segment in the food industry. Although producers increased production to meet growing demand, production historically lagged behind consumption. This gap, along with potentially higher production costs associated with organic production led to price premiums for organic food (Dimitri and Oberholtzer, 2005) compared with non-organic products. For example, supermarket prices for organic milk were 50 to $75 \%$ higher than regular milk during the 1990s (Glaser and Thompson, 2000) and almost 100 percent higher in 2004 (Dimitri and Venezia, 2007).

National comparisons of organic and conventional dairy can be made using the USDA Economic Research Service (2005) Agricultural Resource Management Survey (ARMS). A primary difference between conventional and organic dairy farms is the type of feeding system. Organic dairy farms rely on pasture during the grazing season to a much larger degree than 
their conventional counterparts, which can positively affect whole-farm profitability (Dartt et al., 1999; Tozer et al., 2003). Due to high costs for organic purchased concentrated feed, dairy farms often feed less concentrated feeds to their cows, resulting in production which is, on average, $28 \%$ lower than conventional averages (McBride and Greene, 2007). Research has shown higher profitability for organic milk production due to higher prices received for milk (Butler, 2002; Rotz et al., 2007; Stillman, 2009). Although some research has found organic dairy farms have lower production costs (Stonehouse et al., 2001), most recent studies indicate that organic dairy farms have higher production costs compared with conventional farms (Butler, 2002; Dalton et al., 2008), which is consistent with the USDA ARMS survey (2005) results.

Two strategies for improving economic returns to organic dairy farmers are (1) development of scale economies and (2) decreasing feed purchases by growing higher quality forages and concentrated feed crops on-farm. For example, McBride and Greene (2010) found that increasing herd sizes from 50 to 200 milk cows would decrease total production costs from $\$ 90.78 /$ hectoliter (hL) of milk to around $\$ 56.74 / \mathrm{hL}$ and could increase profits if organic milk prices remain at $\$ 68.09 / \mathrm{hL}$. The McBride and Greene (2010) analysis of the USDA's 2005 ARMS survey suggests potential scale economies exist, given that the average size of an organic dairy farm nationally is 83 cows compared with 156 for conventional dairy farms. Organic dairy farms can also maintain profitability in uncertain economic times by lowering production costs. Purchased feed costs of $\$ 14.87 / \mathrm{hL}$ of milk make up 35\% of total operating costs, which are $\$ 42.35 / \mathrm{hL}$ for a typical United States organic dairy farm (McBride and Greene, 2007) and in Maine as well (Dalton et al., 2008; Cook et al., 2010). This does not necessarily imply that organic dairy farms should decrease protein or energy supplementation, as profitability generally increases with supplementation rate as it does on conventional dairy farms (Soder and Rotz, 2001). Decreasing purchased feed costs by growing concentrate feeds on-farm may not only be more profitable but it may improve environmental sustainability through tighter nutrient cycling (Powell et al., 2010).

Profit comparisons in this analysis are focused on supplemental feeding of stored feeds fed during the non-grazing season with grazing area held constant across different farm sizes. Although pasture situations will change from year to year, pasture area was held constant in this analysis to evaluate the most expensive component of organic dairy systems, the winter feeding strategy selecting appropriate forages and concentrate feeds. Organic dairy farms face challenges and price premiums when including purchased protein in their rations. The range of feed products available to supplement for protein is more limited for organic dairies. Additionally, the average organic protein premium compared with conventional in 2008 was $217 \%$ for organic roasted soybeans [Glycine $\max (\mathrm{L}$.) Merr.], compared with an average energy premium of $213 \%$ (USDA Economic Research Service, 2008; USDA National Agricultural Statistics Service, 2010a) for organic corn (Zea mays L.) grain.

Past research has shown economies of scale in conventional (MacDonald et al., 2007) and organic (Cook et al., 2010) dairy farms as they increase in size and productive capacity. As farms get larger, the mechanized equipment and storages used for feed crops typically increase in size or number. Because pasture (30\% of DMI during grazing season) is now a required component of organic dairy farms (USDA Agricultural Marketing Service, 2010), herd expansion cannot be looked at as the simple answer to improving profitability. It is important to evaluate which organic stored feed production systems using forages and farm-grown or purchased grain best maximizes protein production and profits.

Although past studies have focused on different organic dairy cropping systems, research is lacking on how the favorability of such systems change with increasing farm scale and by adding on-farm grain production. Thus, the goal of this investigation was to simulate the interactive effects of farm size and crop mix on organic dairy farm profitability using the integrated farm system model (IFSM). This crop and livestock simulation model has been used extensively to compare different dairy farm systems (Soder and Rotz, 2001; Rotz et al., $2002,2007)$. The specific objectives of this research were to (1) determine the effects of scale and choice of stored feed cropping systems (concentrated feed and forage) on organic dairy farms and (2) determine the sensitivity of profitability to changes in supplemental protein and energy prices, perennial forage harvest date, soil quality, and milk yield.

\section{MATERIALS AND METHODS}

\section{Integrated Farm System Model}

The IFSM has been used to evaluate dairy, beef, and feed crop production (Rotz et al., 1989, 1999, 2002). The current version 3.2 (Rotz, 2004) of IFSM is based on numerous improvements and modifications to the dairy forage system model (DAFOSYM) originally developed in the mid-1980s. The IFSM is a completely integrated crop and livestock simulation model. It has modules to assess whole-farm economic performance, 
Table 1. Organic dairy livestock inventory, milk production, stand life for grass and pasture, and crop and pasture hectares used by low, medium, and high feed production models

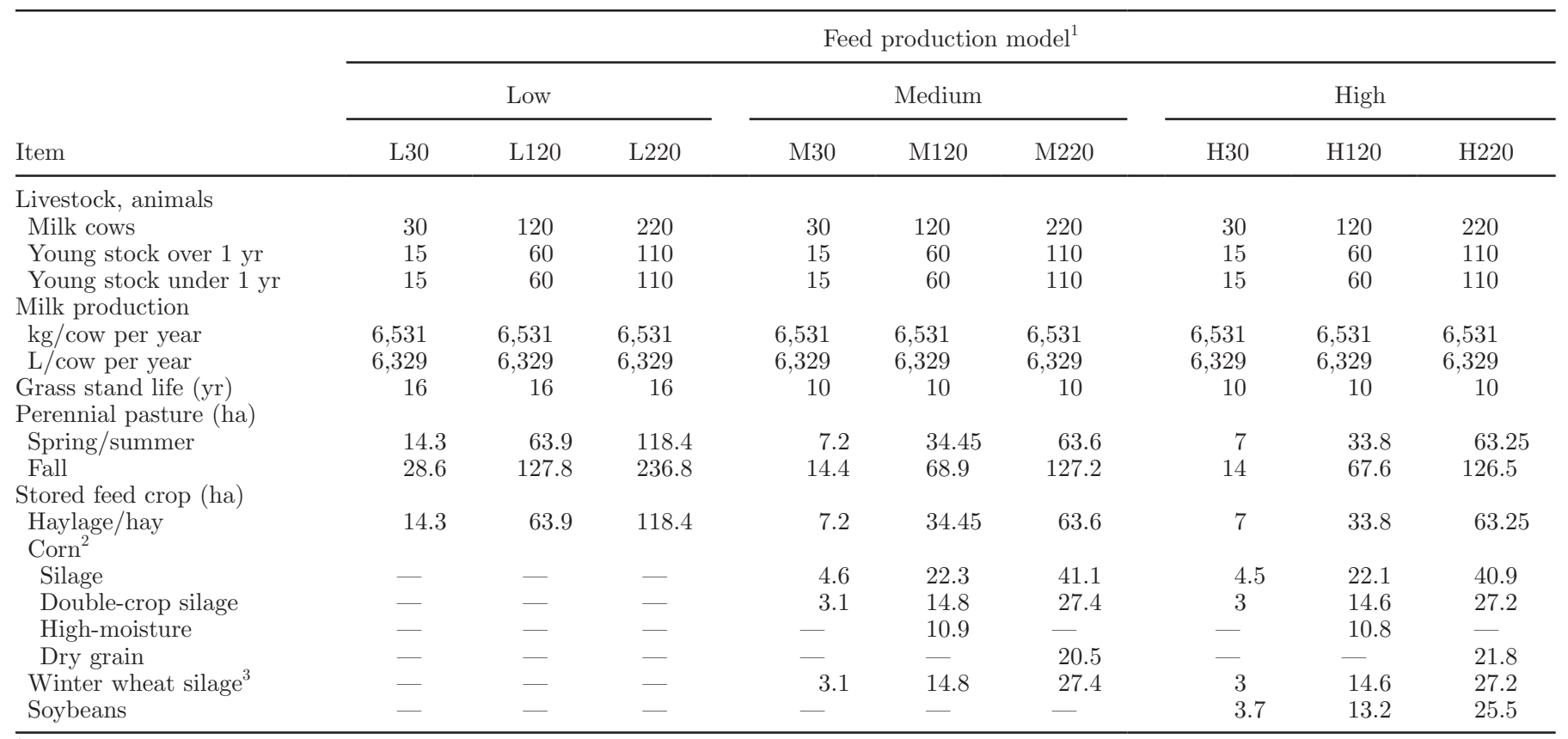

${ }^{1}$ Dairy models are categorized by intensity of equipment use. Low $=$ grass-based forage with purchased concentrated feed; medium $=$ corn silage and grass-based forage with purchased concentrated feed; high = corn and small grain silage plus grass-based forage with purchased and farmgrown concentrated feed. The 30,120, and 220 designations in each scenario [low (L), medium (M), and high (H)] are the number of milk cows with associated heifers, representing small-, medium-, and large-sized organic dairy farms.

${ }^{2}$ Corn grown as regular silage and double cropped with winter wheat. High-moisture (HM) and grain harvest occur for both silage and doublecrop silage; HM corn hectares are averages over those years that HM corn is harvested.

${ }^{3}$ Winter wheat harvested as first-cut silage so able to double crop with corn.

crop production and quality, ruminant feed intake and performance, nutrient dynamics and environmental impacts, and the ability to simulate alternative scenarios (Rotz et al., 2005, 2009), including organic dairy (Rotz et al., 2007), over each year of a 26-year weather period. Crop and pasture growth and yield are predicted daily in metric tons, based on soil water and nutrient availability, ambient temperature, and solar radiation.

According to Rotz et al. (2009), the IFSM uses a linear program as a method to formulate the optimal ration for the simulated dairy herd, given a target milk production set by the user. The linear program methodology balances the ration each year with the least costly purchased feed(s) based on farm-grown feed crop quantity and quality as well as the relative prices of purchased feeds. The least-cost ration is selected according to 5 feed constraints, including minimum amounts of roughage, energy, and protein that need to be met by the ration. Ration balancing using stored or purchased feed is optimized by the IFSM following grazing. Like stored feed crops, grazing stand yield and quality are influenced by annual weather variability in 26 -year data sets. Given a pre-determined level of milk production and pasture area set by the user, annual crop hectares needed to meet feed requirements were determined in the IFSM (Table 1).

To determine economic profitability, a whole-farm budgeting approach is used, which includes both variable and fixed production costs. Annual fixed costs for equipment, buildings, and other infrastructures are the product of their initial costs and a capital recovery factor that is a function of assigned economic life, cost, and the real interest or discount rate. The distribution of simulated annual revenues represents weather-related risk experienced in each production system under a particular weather regimen. For this analysis, one historical weather profile (1980-2005; Waterville, ME) was used and adapted from the National Climatic Data Center (2010). Economic profits and costs simulated in the IFSM were short-run measures for each farm size. Assuming enough time to expand or downsize, short-run average total costs $(\$ /$ cow) can be considered to be long-run average total costs (LR-ATC). At the smallest farm size with the lowest LR-ATC, minimum efficient scale for organic dairy farms was achieved. 


\section{Organic Stored Feed Crop Production Models}

Common assumptions used in this analysis were a soil type common to many Maine organic dairy farms as well as a centrally located weather station (Waterville, ME). Output and input costs used 2008 values, the most recent year of comprehensive economic data available from the organic dairy industry in the United States and Maine. The 3 organic feed systems simulated in this analysis also reflect the major organic dairy stored feed production systems found in New England. However, exact percentages of Maine organic dairy farms using these 3 systems were not available. These organic stored feed production systems complement the grazing strategy commonly used on organic dairy farms in the region. Milk cows are pastured during the spring and summer on half of the farm's perennial forage land, whereas all of this land is fall grazed. Recent organic regulations dictate that $30 \%$ of DMI of dairy cattle must come from grazed forage during the grazing season (USDA Agricultural Marketing Service, 2010); this was easily met with the grazing strategy assumed by all 3 feed systems.

The major differences between the simulated farm operations in this analysis were the machinery and storage needed to produce, harvest, and handle feed. Representative scenarios characterized as low, medium, or high described the intensity of machinery and crop storage for feed production. These scenarios differed by type of $\operatorname{crop}(\mathrm{s})$ used for stored feed production: (1) low relied on perennial sod crops such as grass silage/ legume and dry hay, (2) medium used perennial sod forages as in the low scenario but also included corn silage double-cropped with boot-stage winter wheat ( Triticum aestivum L.) silage, and (3) high had the same forage cropping system as medium but with soybeans in addition to corn grain. Using a factorial treatment structure, each of the 3 feed systems was simulated at 3 scales of production for a total of 9 organic feed production scenarios (Table 1). Cook et al. (2010) influenced selection of 30,120, and 220 milk cows with associated heifers and young stock to represent small, medium, and large-sized organic dairy farms. All feed production scenarios used some combination of purchased or farm-grown organic roasted soybeans and corn grain to balance rations. Default IFSM assumptions of $10 \%$ of the ration as dry hay and a relative high (70\%) forageto-concentrate $(30 \%)$ ratio were retained.

Livestock. According to Cook et al. (2010), about $63 \%$ of organic dairy farms in Maine have Holsteindominated herds with the remaining 37\% comprising other breeds. Holsteins were assumed to weigh $621 \mathrm{~kg}$, producing milk with $3.5 \%$ fat. Similar to approaches used by Dalton et al. (2008), our simulations assumed all farm sizes had equal milk yield of $6,531 \mathrm{~kg} / \mathrm{cow}$ per year (Table 1), as that is how Maine organic dairy farmers conceptualized their production in producer meetings. To evaluate profitability of crop production practices, rations were balanced in the IFSM based on this set level of milk production. All organic feed production scenarios assumed a year-round rather than a seasonal calving strategy. Only $11 \%$ of organic dairy farms surveyed by Cook et al. (2010) calved seasonally. All simulations assumed an equal ratio of young stock to milk cows and an equal proportion of heifers and calves. First-lactation cows accounted for $35 \%$ of the milking herd, comparable to conventional dairy farms in the region.

Feed Crops. Cropland area was sufficient to maintain a zero forage balance over the time period of the simulation (26 yr). Under a zero forage balance, cropland was sufficient to meet the herd's feed requirements. Medium and high 220-cow farms simulated here harvested some corn as grain. Soybean land base for high farms was adjusted for production adequate to feed dairy cattle with no excess soybeans for sale. Perennial sod stands assumed $66 \%$ timothy (Phleum pretense L.) and $34 \%$ alfalfa (Medicago sativa L.). The IFSM perennial stand parameters for orchard grass (Dactylis glomerata L.) and red clover (Trifolium pratense L.) were adjusted to reflect timothy and alfalfa, respectively. Parameters for specific leaf area and maximum rooting depth were changed to more accurately reflect these latter 2 species based on appropriate parameter values for timothy (Woodward, 1983) and alfalfa (Foutz et al., 1976).

Corn was grown in addition to perennial forage for medium and high scenarios, where 30-cow farms harvested all of their corn as silage, whereas larger sizes grew $70 \%$ of corn for silage. For the 120-cow scenario, the remaining $30 \%$ of corn was harvested as highmoisture corn, whereas the 220-cow farm harvested the remainder of the corn as grain. About $40 \%$ of the corn silage land base in medium and high scenarios was double cropped with winter wheat, a typical percentage for growers that double crop to avoid continuous cropping discouraged under organic certification. The ratio of perennial sod to corn land base was based on those for Maine organic dairy farms (Cook et al., 2010). For high scenarios, the same forage cropland base as medium was assumed; however, additional area existed for growing enough soybeans on-farm to be roasted to feed to livestock. Although Maine organic dairy farms have alternatively been experimenting with double-cropping winter grains like triticale (Triticosecale rimpaui Wittm.) with brown midrib sorghum-sudangrass [Sorghum sudanense (Piper) Stapf], a summer forage, these 2 specific crops were not used because the IFSM cannot accommodate such simulations accurately at this time. 
Crop management operations and timing of field operations were typical for the climate zone simulated here (central Maine). Sod crops were assumed to be reseeded every 16 yr for perennial sod-based systems and every $10 \mathrm{yr}$ when in long rotation with row crops. Best practice perennial sod management of 3 cuts was assumed with ideal harvest dates based on observed best crop management practices in Maine. For 30-cow scenarios, ideal harvest dates for first-cut perennial silage was May 31; for second-cut dry hay round bales, July 15; and for third-cut perennial silage, August 25. For larger farm sizes, ideal harvest dates were the same with the first 2 cuts harvested as perennial silage and the third-cut round baled as dry hay. Organic corn production was similar to that of conventional corn, with the exception of 2 cultivations with a rotary hoe 15 and $35 \mathrm{~d}$ post-planting to control weeds. To accommodate planting with winter wheat, double-cropped corn silage was planted $11 \mathrm{~d}$ later and harvested $6 \mathrm{~d}$ earlier than is typical for corn silage not double-cropped with winter wheat. Double-cropped winter wheat in medium and high scenarios was planted by mid-September and harvested as first-cut silage in late May. Winter wheat was used because silage yields for wheat have been competitive with triticale in recent Maine field trials (Jemison, 2008). Weed control in soybeans consisted of 2 rotary hoe operations 10 and $14 \mathrm{~d}$ post-planting.

Under all simulations, manure was deposited by livestock to grazing land. Low feed production scenarios had all stored manure applied to perennial sod crops used for silage, dry hay, and grazing. For medium and high scenarios, $35 \%$ of the stored manure was assumed to be applied to perennial sod ground. The remaining $65 \%$ was applied to row crops, with $60 \%$ applied to corn and $5 \%$ applied to winter wheat. Soybeans received no manure application.

Soils. Our baseline simulations were run using Buxton series soil characteristics (BuB2, 3 to $8 \%$ slopes, eroded) for the shallowest profile depth $(0-30 \mathrm{~cm})$ of these silt loams, rather than the medium $(0-100 \mathrm{~cm})$ depth. These soils are farmed by many organic dairy producers around Waterville in the heart of Maine's dairy belt. Buxton series soils are classified as fine, illitic, frigid Aquic Dystric Eutrudepts. They are very deep, moderately well-drained soils that formed in glaciolacustrine deposits of river valleys (USDA Natural Resources Conservation Service, 2010a). Default soil parameters in the IFSM (version 3.2) were modified to reflect these site-specific dairy soils. Soil characteristic details were extracted from the USDA Natural Resources Conservation Service Web Soil Survey database (USDA Natural Resources Conservation Service, 2010b). The available water-holding capacity for Buxton is $75 \mathrm{~mm}$.
Equipment and Structures. The progression from low to high scenarios required more crop equipment and feed storage facilities to accommodate greater forage diversity and also the production of grains. A general increase in the size of equipment exists as farm size increases. Perennial forage planting as well as planting of wheat were all assumed to be completed with a no-till grain drill. Soybeans were planted with a corn planter. Perennial forages, corn, and wheat silage were harvested with the same forage harvester. All high and medium 120- and 220-cow farms required a combine to harvest corn or soy grain. Forage and grain wagons increased from 30- to 120-cow operations, whereas 220-cow farms used trucks for forage transport to bunker silos. Equipment tractability coefficients were adjusted upward by a maximum of $5.1 \%$ to permit crop operations in all years for medium and high scenarios growing row crops with less surface traction.

Simulations with 30 cows had first-cut perennial silage stored as wrapped round bales. Larger farm sizes used bunker silos for perennial crop silage. Dry hay round bales were stored in a shed with increasing capacity and value with increasing farm scale. Medium and high scenarios assumed the same adequate storage capacity for grain (corn or corn/wheat) silages. Larger operations growing high-moisture or corn grain maintained the same corn silage bunker silo capacity as those not raising grain, because in certain years, no high-moisture or corn grain may have been harvested due to the short growing season. Double-cropped winter wheat silage was ensiled in the same bunker as corn silage. High-moisture corn harvested for 120-cow operations was stored in a stave silo. Corn grain storage cost was based on Rotz et al. (2009), comprising costs for drying ( $\$ 2.21 /$ point of moisture per tonne of $\mathrm{DM})$ and storage $(\$ 9.91 / \mathrm{t}$ of $\mathrm{DM})$. All 30-cow farm scenarios used tie-stall barns with pipeline milking and manure stack pads. Livestock were hand fed silage and grain at this smallest farm size. The 2 larger 120 and 220-cow farms progressed to freestall barns with milk parlors, mechanized TMR feeding with mixer wagons, and concrete tank manure pits. According to Cook et al. (2010), $54 \%$ of Maine's large organic dairy farms surveyed used freestall barns. All farms assumed self-feeding dry hay round bales secured in round bale rings.

Prices. Livestock product output and input prices were assumed constant across all simulations. Prices received for milk, cull cows, heifers, and calves were based on prior surveys of Maine organic dairy farmers (Dalton et al., 2008; Cook et al., 2010). Prices received for any crop used USDA National Agricultural Statistics Service (2010a) organic prices for Maine from 2008. Milk hauling and marketing costs were more realistically based on the 2006 surveyed charge for Maine and 
Vermont (Dalton et al., 2008). Other livestock costs such as breeding, veterinary, insurance, and dues were from the most recent 2008 cost-of-production survey for Maine (Cook et al., 2010). In addition, utilities were notably higher in Maine compared with other states in the Northeast.

The selling price for organic corn silage was obtained from the 2008 ARMS Organic Survey for Maine (USDA National Agricultural Statistics Service, 2010b). For organic hay, buying and selling prices were set equal to $\$ 137.79 / \mathrm{t}$ of $\mathrm{DM}$, which was a typical selling price for Maine. Prices for Midwest organic soybeans and corn grain (USDA Economic Research Service, 2008) were increased to include transportation to Maine (E. Maltby, Northeast Organic Dairy Producers Alliance, Deerfield, MA, personal communication). Soybean prices were increased to include roasting costs consistent with the IFSM's soybean roasting cost of $\$ 35 / \mathrm{t}$ of DM (D. Cunningham, Kern Kirtley \& Herr Elevator, Lebanon, IN, personal communication). Based on these sources, the estimated price per tonne of DM for organic roasted soybeans $(\$ 1,083)$ was over twice the price of corn grain $(\$ 504)$. The IFSM default seed costs for new $(\$ 270 / \mathrm{ha})$ and reseeded $(\$ 20 / \mathrm{ha})$ grassland were used. Seed costs for organic corn, winter wheat, and soybeans were obtained from N. Gamage (Augusta, ME, personal communication), a local livestock supply dealer used by organic dairy farms in Maine.

\section{Feed Crop Model Validation}

Due to a lack of historical county-level field crop data for Maine, simulated corn silage yields were statistically validated against or compared with observed organic feed crop yields from replicated field plots in Orono, Maine (conducted from 2006 to 2007) at 3 research farms: the Smith Farm, the Rogers Farm, and Witter Farm. Statistical validation of corn silage yields to compare observed replicated field trials versus IFSM simulations were possible at the Smith Farm. Here, soils data used for statistical validation were specific to each plot having been surveyed in 2005. Thus, for the Smith Farm, observed corn silage yields were regressed against IFSM simulated yields using SPSS (SPSS Inc., 2007). For Rogers Farm experimental plots, soil profiles were used from the most recent 1993 farm-level soil survey. In contrast to the Smith Farm, Rogers Farm soils and crop yield data were not available at the experimental plot level. Thus, simulated corn silage yields in the IFSM were compared with experimental yield ranges within $95 \%$ confidence intervals of average (2004 to 2008) corn silage yields reported by Jemison (2008).

Because no historical weather data exists for Smith Farm and Rogers Farm, weather at these locations had to be estimated with data from the National Oceanic and Atmospheric Administration Climate Diagnostics Center data repository. These interpolated data for coordinates at the Smith Farm were within $0.75 \mathrm{~km}$ of the experimental field trials conducted at Rogers Farm. Daily precipitation and temperature data for the 26yr time series was taken from the National Oceanic and Atmospheric Administration Climate Prediction Center's unified data set with a $0.25 \times 0.25$ degree latitude and longitude resolution from 1948 to 2008. This particular data set uses a comprehensive archive from weather-gauging networks across the United States (Chen et al., 2008). For both interpolated (Orono) and observed (Waterville) data, solar radiation had to be estimated, as both data sources do not have this IFSM input parameter. Solar radiation was estimated using the RadEst computer program specifying the Campbell-Donatelli model (Donatelli et al., 2003). Simulated solar radiation estimates were validated against $4.5 \mathrm{yr}$ of USDA Agricultural Research Service research farm data in Presque Isle, Maine, with a coefficient of determination of 0.75 generated by the program.

\section{Feed Crop CP Comparisons}

Low, medium, and high feed crop production systems were compared for protein content. This was done for all simulations by simply calculating the $\mathrm{CP}$ content of each crop grown, as the IFSM estimates percent $\mathrm{CP}$ for every crop. The estimated CP percentage was multiplied by the total DM yield to derive crop-related $\mathrm{CP}$ as estimated by the IFSM model. After summing protein produced across all crops, the $\mathrm{CP}$ content was calculated per cow and per hectare for comparisons between perennial sod- and corn-based feed production systems.

\section{Sensitivity Analyses}

To identify variability in net returns between systems, sensitivity analyses were conducted on critical factors influencing profitability that are difficult for farmers to control. These factors are (1) the prices of purchased whole-roasted soybeans and corn grain, (2) delayed harvest dates for perennial sod crop silage and dry hay, and (3) soil quality. The favorability of organic feed systems is highly dependent on the price of purchased concentrated feeds. Exclusive grass/legume silagebased diets from improved perennial stands assumed by all simulations had higher $\mathrm{CP}$ and, thus, required less balancing with roasted soybeans. Corn-based diets in medium and high scenarios needed more soy in the ration to offset the relatively lower protein content of corn silage. As organic roasted soybeans get more ex- 
pensive as they did in 2008 ( $\$ 1,083 / \mathrm{t}$ of $\mathrm{DM})$ compared with organic corn grain $(\$ 504 / \mathrm{t}$ of $\mathrm{DM})$, organic sodbased feed systems in Maine should be more favorable compared with those that are corn-based. Corn-based forage systems would be expected to be more competitive with sod-based systems if corn grain became relatively more expensive compared with roasted soy. For the first sensitivity analysis on the prices of organic concentrated feed, roasted soybean prices were changed from $\$ 600$ to $\$ 1,400 / t$ of DM, whereas corn grain prices were changed from $\$ 100$ to $\$ 900 / t$ of $\mathrm{DM}$ to determine relative effects on profitability for perennial sod- versus corn-based organic feed production systems.

The baseline scenario for simulations assumed a Buxton shallow clay loam combined with ideal harvest dates. A second sensitivity analysis was run on a less favorable case where grass/legume harvest was delayed. Sod crop harvests were delayed roughly 2 wk after ideal harvest dates to June 20 and August 1 for first and second cut, respectively. The third cut was delayed about a month to September 25. Non-optimal delayed harvest should decrease protein content but increase DM yields. Due to the increase in DM production from later forage cuts, crop hectares were adjusted to maintain a zero forage balance for all scenarios where cropland met feed requirements for the herd over the simulation period. A third sensitivity analysis was run assuming a more favorable soil profile using a Buxton medium clay loam with increased soil available water-holding capacity, which is also well represented in the Waterville area. Simulated corn yields were more sensitive to this soil parameter, which should favor corn- over sod-based feed production. Additionally, milk yields were assumed to be 10 to $15 \%$ higher for corn-based scenarios to see how sensitive all prior sensitivity analyses were to potential increased RUP supply from combining corn silage with roasted soybeans.

\section{RESULTS AND DISCUSSION}

\section{Crop Production}

Simulated yields for corn silage and winter wheat silage were compared with replicated experimental research plots at the Smith, Rogers, and Witter Farms in Orono, Maine. Results summarized in Table 2 demonstrate acceptable fits for corn silage and winter wheat silage harvested at the soft dough stage. Corn silage yields were slightly underestimated by the IFSM for Rogers Farm experimental trials (2004-2007), whereas they closely mirrored Smith Farm trials (2006-2007). Regression between observed and simulated yields for Smith Farm corn silage plots had a low fit with a coefficient of determination of 0.23 . However, other yield comparisons for corn silage fell within a $95 \%$ confidence interval of experimental data, as plot-level data were not available. These results were consistent with historical data for organic and conventional farms. Other crop yield comparisons were not as strong. However, this may be attributed to limited plot observations available for field trial data to compare with IFSM simulations.

Total farm production of stored feeds along with feed and supplement purchases and sales are summarized in Table 3. Corn silage displaced perennial sod silage and grazed forage in corn-based systems, whereas the total

Table 2. Integrated farm system model (IFSM) organic simulated dairy feed crop yields (t of DM/ha) using plot- or site-specific soil profiles compared with observed data from Smith Farm and Rogers Farm experimental field trials in Orono, Maine

\begin{tabular}{|c|c|c|c|c|c|}
\hline \multirow[b]{2}{*}{ Comparison $^{1}$} & \multirow[b]{2}{*}{ Mean } & \multirow[b]{2}{*}{ SD } & \multicolumn{2}{|c|}{$\mathrm{CI}^{2}$} & \multirow[b]{2}{*}{$\mathrm{R}^{2}$} \\
\hline & & & $-95 \%$ & $+95 \%$ & \\
\hline \multicolumn{6}{|l|}{ Silage corn } \\
\hline \multicolumn{6}{|l|}{ 2004-2007 } \\
\hline IFSM & 12.87 & 4.82 & - & - & - \\
\hline Rogers Farm & 13.19 & $\mathrm{~N} / \mathrm{A}^{3}$ & 11.86 & 14.50 & - \\
\hline \multicolumn{6}{|l|}{$2006-2007$} \\
\hline IFSM & 8.50 & 1.04 & - & - & 0.23 \\
\hline Smith Farm & 8.49 & 1.45 & 4.67 & 12.31 & - \\
\hline \multicolumn{6}{|c|}{ Winter wheat silage, boot stage } \\
\hline \multicolumn{6}{|l|}{2007} \\
\hline IFSM & 1.29 & - & - & - & - \\
\hline Smith Farm & 1.66 & 0.23 & - & - & - \\
\hline
\end{tabular}

${ }^{1}$ Rogers Farm data is from Jemison (2008), whereas Smith Farm data is from organic dairy forage trials (T. S. Griffin, unpublished data). For silage corn for Smith Farm, plot averages are used for comparison with IFSM simulated yields.

${ }^{2}$ Confidence interval calculated for Smith Farm data. Fisher's least significant difference test was used to calculate the confidence interval by Jemison (2008).

${ }^{3}$ Plot-level data not available (N/A). 
Table 3. Average simulated crop production and sold and purchased feeds and supplements for Waterville, Maine

\begin{tabular}{|c|c|c|c|c|c|c|c|c|c|}
\hline \multirow[b]{2}{*}{ Item } & \multicolumn{9}{|c|}{ Feed production model ${ }^{1}$} \\
\hline & L30 & L120 & L220 & M30 & M120 & M220 & H30 & H120 & $\mathrm{H} 220$ \\
\hline \multicolumn{10}{|c|}{ Stored feed production (t of DM/ha) } \\
\hline Haylage and hay ${ }^{2}$ & 7.38 & 6.73 & 6.67 & 7.50 & 6.66 & 6.72 & 7.58 & 6.81 & 6.74 \\
\hline Grain crop silage & - & - & - & 8.26 & 8.01 & 8.06 & 8.70 & 8.31 & 8.35 \\
\hline Dry grain & - & - & - & - & - & 4.83 & - & - & 5.03 \\
\hline Soybeans & - & - & - & - & - & - & 1.81 & 1.80 & 1.80 \\
\hline \multicolumn{10}{|l|}{ Purchases ( $\mathrm{t}$ of DM) } \\
\hline Grain & 54 & 242 & 408 & 54 & 168 & 270 & 54 & 165 & 261 \\
\hline Soybean seed, roasted & 4 & 17 & 33 & 6 & 22 & 44 & - & - & - \\
\hline Minerals and vitamins & 2 & 6 & 11 & 2 & 6 & 11 & 2 & 6 & 11 \\
\hline Grazed forage consumed & 89 & 362 & 666 & 70 & 308 & 568 & 68 & 305 & 566 \\
\hline \multicolumn{10}{|c|}{ Stored feed production ( $\mathrm{t}$ of $\mathrm{DM} / \mathrm{cow})$} \\
\hline Grain crop silage & - & - & - & 2.13 & 1.96 & 1.96 & 2.17 & 1.96 & 1.96 \\
\hline Winter wheat silage & - & - & - & 0.38 & 0.44 & 0.46 & 0.38 & 0.44 & 0.45 \\
\hline High-moisture grain & - & - & - & - & 0.39 & - & - & 0.42 & - \\
\hline Dry grain & - & - & - & - & - & 0.43 & - & - & 0.47 \\
\hline Soybeans & - & - & - & - & - & - & 0.22 & 0.20 & 0.21 \\
\hline \multicolumn{10}{|l|}{ Purchases ( $\mathrm{t}$ of $\mathrm{DM}$ ) } \\
\hline Grain & 1.80 & 2.02 & 1.85 & 1.80 & 1.40 & 1.23 & 1.80 & 1.38 & 1.19 \\
\hline Soybean seed, roasted & 0.13 & 0.14 & 0.15 & 0.20 & 0.18 & 0.20 & - & - & - \\
\hline Minerals and vitamins & 0.07 & 0.05 & 0.05 & 0.07 & 0.05 & 0.05 & 0.07 & 0.05 & 0.05 \\
\hline Grazed forage consumed & 2.97 & 3.02 & 3.03 & 2.33 & 2.57 & 2.58 & 2.27 & 2.54 & 2.57 \\
\hline \multicolumn{10}{|l|}{ Sales } \\
\hline Forage & - & - & - & - & - & - & - & - & - \\
\hline Soybeans & - & - & - & - & - & - & - & - & - \\
\hline
\end{tabular}

${ }^{1}$ Dairy models are categorized by intensity of equipment use. Low $=$ grass-based forage with purchased concentrated feed; medium $=$ corn silage and grass-based forage with purchased concentrated feed; high = corn and small grain silage plus grass-based forage with purchased and farmgrown concentrated feed. The 30,120, and 220 designations in each scenario [low (L), medium (M), and high (H)] are the number of milk cows with associated heifers, representing small-, medium-, and large-sized organic dairy farms.

${ }^{2}$ Includes both low-quality and high-quality harvested grass.

grazed and stored forage base yields remained within $2.2 \%$ across similar sized scenarios. Large corn-based systems growing high-moisture corn and corn grain for concentrated feed used less purchased grain per cow. Low 120- and 220-cow farms with a perennial forage base had a higher need for energy to balance the ration, requiring, on average, more organic corn grain (1.935 t of $\mathrm{DM} / \mathrm{cow}$ ) compared with medium (1.315 t of DM/ cow) and high (1.285 t of DM/cow) scenarios. Organic corn grain used per cow was similar for low scenarios due to more similar energy and NDF concentration of perennial sod compared with corn silage. Corn-based systems had a greater protein requirement; medium and high scenarios required about $0.20 \mathrm{t}$ of $\mathrm{DM}$ of supplemental purchased protein grain/cow, compared with $0.14 \mathrm{t}$ of $\mathrm{DM}$ of protein grain/cow for low scenarios. Total purchased organic corn grain and roasted soybeans decreased from low to medium to high scenarios. Purchased corn decreased as corn-based farms got larger due to high-moisture or dry corn grain grown on-farm. Farm simulations for high scenarios purchased no roasted soybeans because these were grown, roasted, and fed on-farm. Thus off-farm grain purchases were the least for high 220 farms.

Perennial forage and corn silage yields were higher for 30-cow scenarios compared with larger sizes (Table 3). This was due to decreases in harvest loss for small farms, as crops can be harvested more quickly at this scale. By comparison, 120-cow scenarios had greater harvest loss because crop acreage increased proportionately more than equipment size. Larger 220-cow operations used robust equipment such as a self-propelled forage harvester that sped chopping of perennial silage while decreasing harvest losses.

Low feed production systems generated the highest crop protein production per cow and per hectare (Table 4). The CP concentration was higher for harvested perennial forage (19\%) than for corn silage $(10 \%)$ and winter wheat silage harvested at the boot stage (11\%). After averaging crop yields in Table 3, the DM yield 
of $6.98 \mathrm{t}$ of $\mathrm{DM} /$ ha for perennial silage was slightly less than corn (8.28) double cropped with winter wheat silage (3.66). These results assume that sod was cut at optimum harvest dates for first (May 31), second (July 15), and third (August 25) cut. Forages for medium and high production systems included corn silage in addition to sod. Consequently, the lower $\mathrm{CP}$ content of the forage components of these rations must be balanced with protein from concentrated feeds. For high scenarios, on-farm grown and roasted soybeans helped in balancing the ration. For medium scenarios, roasted soybeans were purchased and were, thus, not included in the CP summary of crops shown in Table 4. Soybeans incrementally improved $\mathrm{CP}$ feed production per cow for high farm simulations.

\section{Economics}

Results confirmed potential for Northeast organic dairy farms to increase profitability through economies of scale by operating at a minimum efficient scale closer to 220 milk cows. Assuming enough time for farmers to expand from smaller to larger sizes, LR-ATC (measured in $\$ /$ cow) decreased as farm size increased for all feed production systems evaluated (Table 5). Because milk production was assumed constant across all simulation sizes and feed production systems, lower LR-ATC with increasing organic dairy farm size resulted in increased net farm income (NFI) per cow. These results suggest most organic dairy farmers in Maine are operating below minimum efficient scale and could look to increase profitability through expansion, regardless of the feed production system they are using. For example, about $87 \%$ of Maine's organic dairy farms surveyed in 2008 by Cook et al. (2010) had fewer than 175 cows with the remaining $13 \%$ between 201 and 275 cows.

However, Maine organic dairy farms will likely not be able to expand to benefit from scale economies for several reasons. First, demand for organic milk has been stagnant. Second, Maine faces biophysical and landscape constraints. For example, most of Maine's organic dairy farms manage a fragmented landscape of smaller fields. Such agricultural topography could limit farm expansion. Third, adequate pasture may be limited during the grazing season for large farms due to new grazing requirements (30\% DMI from pasture during the grazing season) in the National Organic Program (USDA Agricultural Marketing Service, 2010). Although a few larger organic dairy farms in Maine have met grazing requirements at the 220-cow level, expansion beyond this size may be challenging. Finally, some producers may not want to expand due to personal management goals and quality of life considerations.

Perennial sod-based farms (low) were more profitable than corn-based (medium and high) except at the largest 220-cow size. For 30- and 120-cow scenarios,

Table 4. Simulated CP ( $\mathrm{t}$ of DM/cow and $\mathrm{t}$ of DM/ha) produced by farm-grown feed crops for low, medium, and high feed production models

\begin{tabular}{|c|c|c|c|c|c|c|c|c|c|}
\hline Stored feed crop & \multicolumn{9}{|c|}{ Feed production model $^{1}$} \\
\hline \multicolumn{10}{|l|}{$\mathrm{t}$ of $\mathrm{DM} / \mathrm{cow}$} \\
\hline Haylage/hay & 1.563 & 1.579 & 1.594 & 0.800 & 0.852 & 0.866 & 0.787 & 0.852 & 0.865 \\
\hline \multicolumn{10}{|l|}{ Corn } \\
\hline Grain & - & - & - & - & - & 0.050 & - & - & 0.056 \\
\hline Wheat silage & - & - & - & 0.049 & 0.054 & 0.054 & 0.047 & 0.053 & 0.053 \\
\hline Soybeans & - & - & - & - & - & - & 0.107 & 0.095 & 0.099 \\
\hline Total feed crops & 1.563 & 1.579 & 1.594 & 1.091 & 1.156 & 1.165 & 1.189 & 1.255 & 1.268 \\
\hline \multicolumn{10}{|l|}{$\mathrm{t}$ of $\mathrm{DM} / \mathrm{ha}^{2}$} \\
\hline Haylage/hay & 1.644 & 1.484 & 1.481 & 1.080 & 0.964 & 0.974 & 0.934 & 0.870 & 0.864 \\
\hline \multicolumn{10}{|l|}{ Corn } \\
\hline Total feed crops & 1.644 & 1.484 & 1.481 & 1.473 & 1.308 & 1.310 & 1.411 & 1.282 & 1.267 \\
\hline
\end{tabular}

${ }^{1}$ Dairy models are categorized by intensity of equipment use. Low $=$ grass-based forage with purchased concentrated feed; medium $=$ corn silage and grass-based forage with purchased concentrated feed; high = corn and small grain silage plus grass-based forage with purchased and farmgrown concentrated feed. The 30,120, and 220 designations in each scenario [low (L), medium (M), and high (H)] are the number of milk cows with associated heifers, representing small-, medium-, and large-sized organic dairy farms.

${ }^{2}$ Simulated CP contribution per hectare from individual crops calculated by dividing by total feed crop area, not by individual crop area. 
Table 5. Organic dairy total revenues, costs, and profits for low, medium, and high feed production models $(\$ /$ cow $)$

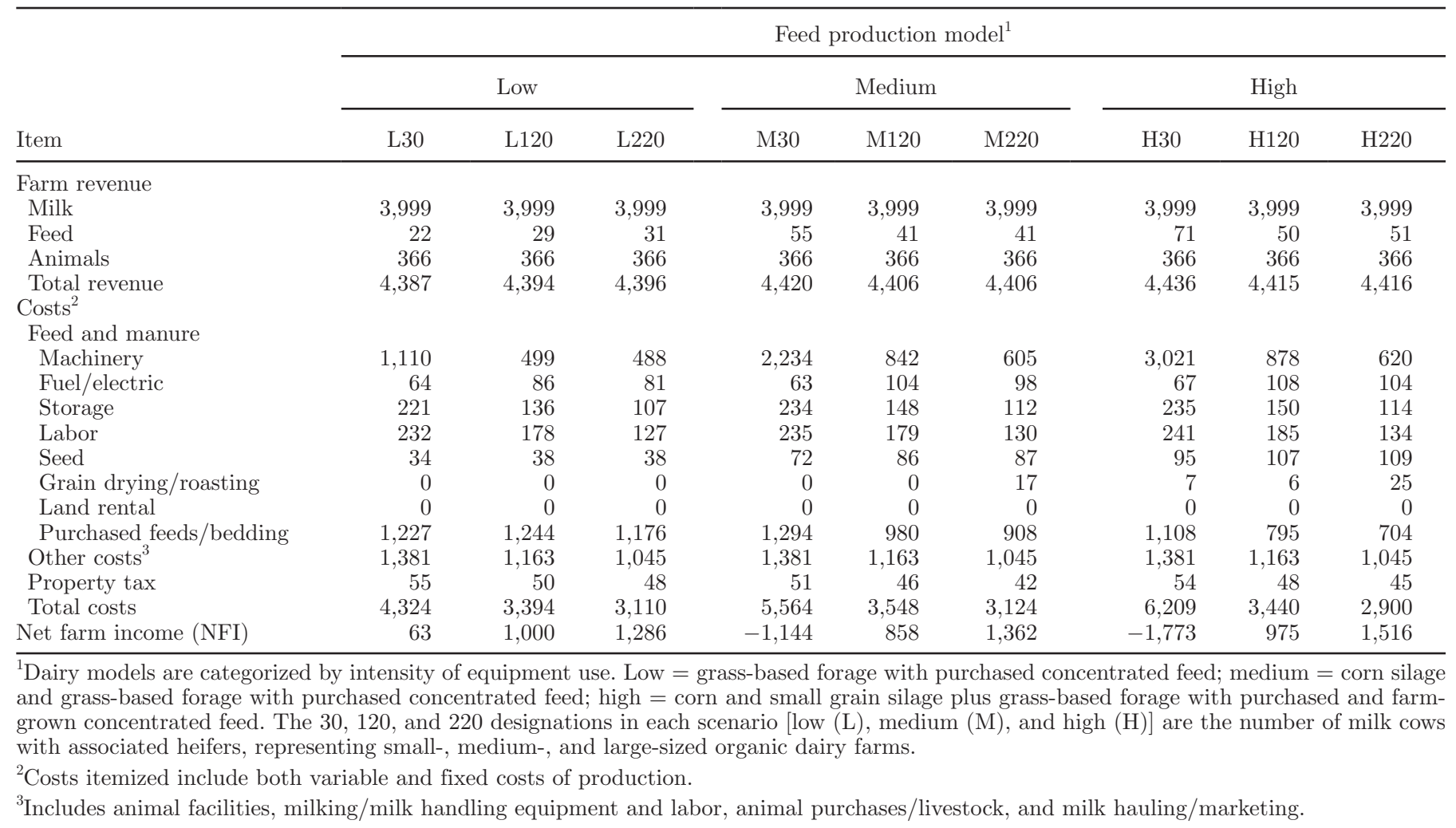

sod-based stored feed systems had a competitive edge compared with corn and small grain silage systems because corn and winter wheat require more capital investment in equipment and storage facilities. This is especially true for smaller 30-cow sizes where equipment costs per cow are prohibitively high. Efficient scale is reached for corn-based feed production systems around 220 cows. At this size, the LR-ATC was lower and profits were greater for corn-based compared with sod-based systems (Table 5).

If large organic dairy farmers grow corn, especially if corn is harvested as dry or high-moisture grain in addition to silage, they would benefit by growing and feeding soybeans. Soybeans require minimal additional investment in harvest, storage, and processing equipment. Farms harvesting corn as grain already have a combine that can be used for soybeans; however, more land and storage capacity would be needed. The economic efficiency of growing soybeans is illustrated by the greater NFI per cow of high $220(\$ 1,516)$ compared with medium $220(\$ 1,362)$ farms in Table 5. Larger organic dairy farms that already have invested in combines for harvesting grain may be able to increase return on investment by using the equipment over more hectares to harvest soybeans. If larger organic dairy farmers make capital investments in combines for har- vesting grain, they may as well grow their own protein and decrease their feed costs.

Additional benefits to on-farm concentrated feed production include encouraging tighter nutrient cycling to mitigate soil nutrient loading from purchased grain nutrients as well as greater self-sufficiency and quality control in crop production. Improved self-sufficiency may serve to buffer farms from future shortages in organic livestock feeds considering recent price volatility in organic and conventional grain markets.

\section{Small Organic Dairy Farms}

The NFI per cow for the medium $(-\$ 1,144)$ and high $(-\$ 1,773)$ smallest 30 -cow scenarios were unprofitable (Table 5). However, this lack of profitability assumed farmers did not custom hire any crop operations. Our base assumptions that farmers would own expensive corn and soybean harvest equipment to manage only 3.7 ha of soybeans or 7.6 ha of corn silage (Table 1) are unrealistic for just these 2 scenarios. Thus, it was assumed all row crop production was custom-hired for these 2 scenarios. Revised economic results for these 2 cases are not included in tables. The NFI per cow for medium and high scenarios improved to $-\$ 376$ and - $\$ 210$ respectively, compared with $\$ 63$ for the low 30 - 
cow case. Assuming all 30-cow scenarios custom-hired all crop operations including those for perennial forage, the NFI per cow for high (\$458) exceeded that for low (\$349) and medium (\$297) scenarios. Most small organic dairy farms in Maine do not custom-hire for perennial forage. However, these simulations support custom-hiring as a strategy for smaller organic dairy farms if custom-hiring expands as an industry in Maine.

It is important to recall that our analysis assumed that milk yields were constant across all feed production scenarios and farm sizes. Although it is realistic to expect organic dairy farmers to meet target milk yields assumed by this analysis, some smaller organic producers in Maine have cut back on purchased concentrated feeds due to high grain prices or feed no grain at all. Although this may be against their economic self-interest, Cook et al. (2010) documented milk yield averages for surveyed 30-cow farms to be only 4,359 $\mathrm{kg} /$ cow per year compared with the $6,531 \mathrm{~kg} / \mathrm{cow}$ per year assumed for all feed production simulations in our analyses. These producers are likely perennial sod-based with a low feed production system. However, at only $4,359 \mathrm{~kg} / \mathrm{cow}$ per year, these smaller Maine organic dairy farms were not economically competitive, with an estimated NFI of $-\$ 750 /$ cow. Thus, it is useful to determine how much higher milk production for the low 30-cow case needed to be in order have the same level of NFI as similar-sized medium and high operations that assumed custom-hiring of row crops but not perennial forage production. For these 30-cow scenarios, low farms broke even with medium farms at $5,354 \mathrm{~kg} /$ cow per year and with high farms at $5,802 \mathrm{~kg} /$ cow per year. This suggests that smaller 30-cow sod-based organic dairy farms in Maine need to increase grain supplementation to achieve higher milk production over a baseline of $4,359 \mathrm{~kg} / \mathrm{cow}$ per year to be more economically competitive with similar-sized organic dairy farms using corn-based forage production systems where row crop operations are custom-hired.

\section{Sensitivity Analyses}

Purchased Concentrate Prices. In Table 6, sensitivity analyses of roasted organic soybean prices show that it is profitable for corn-based feed production systems to grow soybeans at all price levels ( $\$ 600$ to $\$ 1,400 / \mathrm{t}$ of DM). High scenarios were always more profitable or lost less money than medium scenarios. Also consistent across all roasted soybean prices was the low farm's greater profitability over high and medium at the smallest farm size, whereas high and medium farms were more profitable than low farms at the largest 220-cow size. At the intermediate 120-cow size, low farms were more profitable than medium farms over all simulated prices for organic roasted soybeans. At this size, low farms were also more profitable than high farms at most simulated prices. However, when organic roasted soybeans exceed $\$ 1,188 / \mathrm{t}$ of $\mathrm{DM}$, high 120 farms became more profitable than low 120 farms. This suggests that if organic roasted soybean prices meet or exceed the price ratio to corn grain observed in 2008, growing and processing soybeans on-farm in a corn-based system becomes more economically beneficial than purchasing this concentrated feed under a sod-based system at an intermediate farm size of 120 cows. The higher cost of purchased feed at the margin for low 120 farms outweighed the high average fixed costs of not growing soybeans closer to minimum efficient scale for high 120 farms.

A second sensitivity analysis changed organic corn grain prices from $\$ 100$ to $\$ 900 / \mathrm{t}$ of $\mathrm{DM}$. Low farms were more profitable than medium and high at the 30 - and 120-cow size only when corn grain prices were relatively low. When organic corn grain prices for 120cow scenarios exceeded $\$ 544.50$ and $\$ 739 / \mathrm{t}$ of $\mathrm{DM}$, low scenarios became less profitable than high and medium, respectively. Considering that 2008 prices for organic corn grain averaged $\$ 504 / \mathrm{t}$ of $\mathrm{DM}$ and then peaked at $\$ 573 / \mathrm{t}$ of $\mathrm{DM}$, these results suggest that the economic favorability of sod-based organic dairy feed production systems is sensitive to maintenance of historically lower prices of organic corn grain (relative to prices of roasted soybeans) relied on to balance rations. For larger 220cow operations, low farms were less profitable than medium and high unless organic corn grain prices fell below $\$ 381.90$ and $\$ 160.50 / \mathrm{t}$ of $\mathrm{DM}$, respectively. This suggests perennial sod-based organic dairy farms could improve profitability relative to those that are corn based if organic corn grain prices decrease from more organic corn being grown either on-farm, by other farmers, or if other sources of concentrated feed energy (small grains) become available at competitive prices.

The sensitivity analyses in Table 6 assumed noncorrelated prices where the price of the other feed grain was held constant. Prices for organic roasted soybeans and corn grain have historically been correlated. Three additional IFSM scenarios were run for correlated organic roasted soybean and corn grain prices measured in $\$ / \mathrm{t}$ of DM: (1) high/high $(\$ 1,400 / \$ 900)$, (2) medium/ medium $(\$ 1,000 / \$ 500)$, and (3) low/low $(\$ 600 / \$ 100)$. These scenarios had soybean-to-corn grain price ratios of $1.56,2$, and 6 , respectively. Net farm income $(\$ /$ cow $)$ for these 3 scenarios (data not shown) were consistent with non-correlated price sensitivity analyses with soybean-to-corn grain price ratios ranging from 1.10 to 9.92 (Table 6). Thus, the economic favorability of the cropping systems analyzed is affected by the relative price ratio between organic roasted soybeans and corn 
Table 6. Sensitivity analyses of changing purchased roasted soybean and corn grain price $(\$ / t$ of DM) on net farm income (NFI) for low, medium, and high organic feed production models $(\$ /$ cow $)$

\begin{tabular}{|c|c|c|c|c|c|c|c|c|c|c|}
\hline Item & $\begin{array}{l}\text { Soy/corn } \\
\text { price ratio }\end{array}$ & \multicolumn{9}{|c|}{ Feed production model $^{1}$} \\
\hline \multicolumn{11}{|c|}{ Roasted soy price ${ }^{2}$} \\
\hline$\$ 1,400$ & 2.78 & 3 & 941 & 1,224 & $-1,226$ & 779 & 1,281 & $-1,777$ & 969 & 1,508 \\
\hline$\$ 1,300$ & 2.58 & 17 & 955 & 1,239 & $-1,206$ & 798 & 1,301 & $-1,776$ & 970 & 1,510 \\
\hline$\$ 1,000$ & 1.98 & 61 & 997 & 1,284 & $-1,147$ & 854 & 1,361 & $-1,774$ & 973 & 1,515 \\
\hline$\$ 900$ & 1.78 & 76 & 1,011 & 1,300 & $-1,127$ & 872 & 1,381 & $-1,773$ & 974 & 1,516 \\
\hline$\$ 800$ & 1.59 & 91 & 1,025 & 1,315 & $-1,107$ & 891 & 1,401 & $-1,772$ & 975 & 1,518 \\
\hline$\$ 700$ & 1.39 & 105 & 1,040 & 1,330 & $-1,087$ & 910 & 1,421 & $-1,771$ & 976 & 1,520 \\
\hline$\$ 600$ & 1.19 & 120 & 1,054 & 1,345 & $-1,067$ & 928 & 1,441 & $-1,770$ & 977 & 1,521 \\
\hline \multicolumn{11}{|c|}{ Corn grain price ${ }^{3}$} \\
\hline$\$ 900$ & 1.10 & -654 & 201 & 552 & $-1,858$ & 299 & 877 & $-2,486$ & 426 & 1,045 \\
\hline$\$ 300$ & 3.31 & 433 & 1,411 & 1,665 & -777 & 1,142 & 1,613 & $-1,405$ & 1,256 & 1,758 \\
\hline$\$ 200$ & 4.96 & 614 & 1,612 & 1,850 & -596 & 1,283 & 1,736 & $-1,225$ & 1,394 & 1,876 \\
\hline$\$ 100$ & 9.92 & 795 & 1,814 & 2,035 & -416 & 1,423 & 1,859 & $-1,045$ & 1,532 & 1,995 \\
\hline
\end{tabular}

${ }^{1}$ Dairy models are categorized by intensity of equipment use. Low $=$ grass-based forage with purchased concentrated feed; medium $=$ corn silage and grass-based forage with purchased concentrated feed; high = corn and small grain silage plus grass-based forage with purchased and farmgrown concentrated feed. The 30, 120, and 220 designations in each scenario [low (L), medium (M), and high (H)] are the number of milk cows with associated heifers, representing small-, medium-, and large-sized organic dairy farms.

${ }^{2}$ Corn grain price held at baseline of $\$ 504 / \mathrm{t}$ of DM, an average price observed in 2008.

${ }^{3}$ Roasted soy price held at baseline of $\$ 992 / \mathrm{t}$ of DM, falling within the range of prices observed in 2008.

grain, regardless of the degree of correlation between prices.

Perennial Forage Quality. Timely perennial forage harvest is critical to maintaining profitability in perennial sod-based systems. A more unfavorable scenario was run with delayed harvest dates for sod. Delayed harvest dates for first (June 20), second (August 1), and third (September 25) cuts decreased perennial forage quality. Delayed sod harvest lowered CP content and total digestible nutrients, while increasing NDF. This lower protein and energy content and decreased digestibility of perennial forage required 5 to $7 \%$ more purchased corn grain to balance the ration. This contributed to around a $\$ 40 /$ cow decrease in NFI averaged across all 9 simulations. Even in situations with compromised perennial forage quality from delayed harvest, sod-based systems were still economically competitive with corn-based systems, especially if organic corn grain prices remained below $\$ 460 / \mathrm{t}$ of $\mathrm{DM}$ as observed during December of 2008.

Soil Quality. Simulations of baseline and more favorable soil and crop quality represent observed conditions in Maine. Relative to baseline simulations, a more favorable scenario of ideal perennial sod harvest dates combined with a Buxton medium clay loam with higher available water capacity resulted in improved perennial forage quality with slightly higher CP and total digestible nutrients and lower NDF. In addition, sod-based scenarios also bought $6 \%$ less grain due to the higher nutritional value of perennial silage grown in a medium clay loam, resulting in an average profitability increase of $\$ 51 /$ cow. Although perennial sod yields in the IFSM under Buxton medium clay loam did not change much from the shallower soil profile, the higher available water capacity for this Buxton soil improved corn silage DM yields by $40 \%$ from an average of 8.28 $\mathrm{t}$ of DM (baseline runs) to an average of $11.6 \mathrm{t}$ of DM. Consequently, corn-based systems were more competitive economically, on average, than sod-based systems, as $23 \%$ less grain was purchased, which improved NFI by $\$ 152 /$ cow. Increased competitiveness of corn-based systems due to improved yield response of corn on Buxton medium clay loam caused high farms to be more profitable than low at the 120-cow level.

These results suggest that corn-based systems can be preferable economically for organic dairy farmers compared with sod-based ones when (1) soil profiles are deeper with improved available water capacity and (2) prices are lower for supplemental protein and higher for supplemental energy than those observed in 2008. 
Corn-based systems require more purchased soybean protein to balance the ration than sod-based systems due to the lower CP content of corn (10\%) compared with perennial forage (20\%) assumed by the IFSM. Thus, lower protein prices enhance the favorability of corn over perennial silage. Likewise sod-based systems require more purchased energy in the form of corn grain to balance the ration than corn-based systems due to the higher per-unit $\mathrm{NE}_{\mathrm{L}}$ of corn silage compared with perennial silage.

Milk Yield. The IFSM results and sensitivity analyses so far have assumed a fixed level of milk output of $6,531 \mathrm{~kg} / \mathrm{cow}$ per year. However, rations with higher RUP, such as those that combine corn silage with roasted soybeans, may improve milk production. All previous sensitivity analyses were run assuming corn-based medium and high scenarios had 10 and $15 \%$ higher milk yields of 7,174 and $7,500 \mathrm{~kg} /$ cow per year, respectively. This assumed more grain was purchased and fed to achieve these higher milk yields. Corn-based scenarios with 120 and 220 cows were now more profitable than grass-based ones assuming 10\% higher milk yield. Corn-based scenarios with 120 cows were not as profitable as those that were grass-based only when organic corn grain prices were less than one-fifth the price of organic roasted soybeans. For the smaller 30-cow size, the grass-based low scenario remained more profitable than medium and high 30-cow scenarios feeding corn.

\section{CONCLUSIONS}

Given recent price volatility of organic concentrated feed crops (e.g., corn grain and roasted soybeans), Maine organic dairy farmers have sought to increase profitability by maximizing on-farm production of protein and energy in forages and concentrated feed crops. However, it has been unclear whether perennial sod- or corn-based forage systems and growing soybeans on-farm best accomplish this objective under different scales of organic dairy production. Results indicate that the economic favorability of these 2 forage systems is strongly dependent on organic dairy farm size. Maximizing on-farm cropping systems to decrease feed purchases and improve profitability is more economically feasible for large organic dairy farms growing corn-based forage plus soybeans. For large organic dairy farms managing 220 milk cows, row crop production of soybeans and corn is large enough to be closer to efficient scale of production compared with smaller farm sizes. Even though large corn-based organic dairy farms growing, roasting, and feeding soybeans minimize grain purchases, some farmers may not have the time or desire to devote to managing soybean and corn crops or expand to the hectares necessary to achieve economies of scale. This suggests economic opportunities may exist for third-party organic farmers to diversify their operations by growing concentrated feeds more locally in Maine. Off-farm grain inputs can still be substantially decreased if ideal perennial forage harvest dates are met to maximize forage quality. Even though sod-based organic dairy farms need to import more grain, this system is ideal for small farms due to lower equipment and storage costs. Smaller organic dairy farmers on soils with shallower profiles and lower available water capacity should be most profitable if they are exclusively sod-based. Larger organic dairy farms on deeper soils stand to improve economically if they are corn based. These large farms are best positioned to decrease off-farm grain purchases, improve profitability, and tighten nutrient cycling, especially if soybeans are produced and fed on-farm. It is important to note that reported results are based on IFSM model simulations, which may not reflect real-world situations. Thus, interpretation of results should be done with caution taking this into account. Future research should be conducted to better quantify environmental impacts of organic dairy systems at multiple scales as well as identify production risks across different soil and weather regimens in Maine.

\section{ACKNOWLEDGMENTS}

The authors thank Al Rotz (USDA-ARS, University Park, PA) for educating us about the IFSM and for guiding us through model calibration and validation, as well as 2 anonymous reviewers for improving the quality of this manuscript. We also thank Julia Simons and Zach Conrad (both of the Friedman School of Nutrition Science and Policy, Tufts University, Boston, MA) for conducting background research on organic dairy. Peggy Pinette (USDA-ARS, New England Plant, Soil and Water Laboratory, Orono, ME) and Thomas Molloy (Plant, Soil, and Environmental Sciences, University of Maine, Orono) provided organic dairy forage data for Rogers, Smith, and Witter Farms in Orono, Maine. We are also grateful to Dave Marcinkowski (Department of Animal and Veterinary Sciences, University of Maine, Orono) for providing background and analysis on the organic dairy feeding trials at the University of New Hampshire (Durham) and University of Maine (Orono). John Jemison (University of Maine Cooperative Extension, Orono) answered questions about organic dairy forage trials at the University of Maine. This research was made possible through support from a USDA Cooperative State Research, Education, and Extension Service (CSREES) Integrated Organic Program project (number ME02005-04474) titled "Reducing off-farm grain inputs on Northeast organic dairy farms." 


\section{REFERENCES}

Butler, L. J. 2002. The economics of organic milk production in California: A comparison with conventional costs. Am. J. Altern. Agric. $17: 83-91$.

Chen, M., W. Shi, P. Xie, V. B. S. Silva, V. E. Kousky, R. W. Higgins, and J. E. Janowiak. 2008. Assessing objective techniques for gauge-based analyses of global daily precipitation. J. Geophys. Res. 113:D04110 doi:10.1029/2007JD009132.

Cook, A. L., P. S. Heacock, G. K. Criner, and L. A. Bragg. 2010. Organic Milk Production in Maine: Attributes, Costs, and Returns. Maine Agricultural and Forest Experiment Station Technical Bulletin 204. The University of Maine, Orono.

Dalton, T. J., R. Parsons, R. Kersbergen, G. Rogers, D. Kauppila, L. McCrory, L. A. Bragg, and Q. Wang. 2008. A Comparative Analysis of Organic Dairy Farms in Maine and Vermont: Farm Financial Information from 2004 to 2006. Maine Agricultural and Forest Experiment Station Bulletin 851. The University of Maine, Orono.

Dartt, B. A., J. W. Lloyd, B. R. Radke, J. R. Black, and J. B. Kaneene. 1999. A Comparison of profitability and economic efficiencies between management-intensive grazing and conventionally managed dairies in Michigan. J. Dairy Sci. 82:2412-2420.

Dimitri, C., and L. Oberholtzer. 2005. Market-Led Versus Government-Facilitated Growth: Development of the U.S. and EU Organic Agricultural Sectors. WRS-05-05. US Department of Agriculture, Economic Research Service, Washington, DC.

Dimitri, C., and K. M. Venezia. 2007. Retail and Consumer Aspects of the Organic Milk Market. LDP-M-155-01. US Department of Agriculture, Economic Research Service, Washington, DC.

Donatelli, M., G. Bellocchi, and F. Fontana. 2003. RadEst3.00: Software to estimate daily radiation data from commonly available meteorological variables. Eur. J. Agron. 18:363-367.

Foutz, A. L., W. Wilhelm, and A. K. Dobrenz. 1976. Relationship between physiological and morphological characteristics and yield of nondormant alfalfa clones. Agron. J. 68:587-591.

Glaser, L. K. and G. D. Thompson. 2000. Demand for organic and conventional beverage milk. Paper no. 36346 in Proc. Western Agricultural Economics Association Annual Meetings, Vancouver, British Columbia, Canada.

Greene, C., C. Dimitri, B.-H. Lin, W. McBride, L. Oberholtzer, and T. Smith. 2009. Emerging Issues in the U.S. Organic Industry. Economic Information Bulletin (EIB) 55. US Department of Agriculture, Economic Research Service, Washington, DC.

Jemison, J. M. 2008. Assessing alternative forage production systems for organic dairies in New England. Forage and Grazinglands doi:10.1094/FG-2008-1103-02-RS.

MacDonald, J. M., E. J. O'Donoghue, W. D. McBride, R. F. Nehring, C. L. Sandretto, and R. Mosheim. 2007. Profits, Costs, and the Changing Structure of Dairy Farming. Economic Research Report Number 47, US Department of Agriculture, Economic Research Service, Washington, DC.

McBride, W. D., and C. Greene. 2007. A comparison of conventional and organic milk production systems in the U.S. Paper no. 9680 in Proc. American Agricultural Economics Association Annual Meeting, Portland, OR.

McBride, W. D., and C. Greene. 2010. Organic dairy sector evolves to meet changing demand. Amber Waves 8:28-33.

National Climatic Data Center. 2010. National Climatic Data Center, National Oceanic and Atmospheric Administration (NOAA) Satellite and Information Service. Accessed May 17, 2010. http://www. ncdc.noaa.gov/oa/ncdc.html.

Powell, J. M., M. P. Russelle, and N. P. Martin. 2010. Trends in the dairy industry and their implications for producers and the environment. Pages 115-139 in Livestock in a Changing Landscape, Vol. 2. P. Gerber, H. A. Mooney, J. Dijkman, S. Tarawali, and C. de Haan, ed. Island Press, Washington, DC.

Rotz, C.A. 2004. The integrated farm system model: A tool for developing more economically and environmentally sustainable farming systems for the Northeast. Paper No. NABEC 04-0022 in 2004 Special Meeting Papers. American Society of Agricultural and Biological Engineers, St. Joseph, MI.

Rotz, C. A., J. R. Black, D. R. Mertens, and D. R. Buckmaster. 1989. DAFOSYM: A model of the dairy forage system. J. Prod. Agric. 2:83-91.

Rotz, C. A., D. R. Buckmaster, and J. W. Comerford. 2005. A beef herd model for simulating feed intake, animal performance, and manure excretion in farm systems. J. Anim. Sci. 83:231-242.

Rotz, C. A., M. S. Corson, D. S. Chianese, and C. U. Coiner. 2009. The Integrated Farm System Model: Reference Manual, Version 3.2. US Department of Agriculture, Agricultural Research Service, Washington, DC.

Rotz, C. A., G. H. Kamphuis, H. D. Karsten, and R. D. Weaver. 2007. Organic dairy production systems in Pennsylvania: A case study evaluation. J. Dairy Sci. 90:3961-3979.

Rotz, C. A., D. R. Mertens, D. R. Buckmaster, M. S. Allen, and J. H. Harrison. 1999. A dairy herd model for use in whole farm simulations. J. Dairy Sci. 82:2826-2840.

Rotz, C. A., A. N. Sharpley, L. D. Satter, W. J. Gburek, and M. A. Sanderson. 2002. Production and feeding strategies for phosphorus management on dairy farms. J. Dairy Sci. 85:3142-3153.

Soder, K. J., and C. A. Rotz. 2001. Economic and environmental impact of four levels of concentrate supplementation in grazing dairy herds. J. Dairy Sci. 84:2560-2572.

SPSS Inc. 2007. SPSS Manual. Version 16.0. SPSS Inc., IBM Corp., Somers, NY.

Stillman, R. 2009. Livestock, dairy, and poultry outlook. LDP-M-175. US Department of Agriculture, Economic Research Service, Washington, DC. Accessed May 14, 2010. http://www.ers.usda.gov/ publications/ldp/2009/05May/ldpm179.pdf.

Stonehouse, D. P., E. A. Clark, and Y. A. Ogini. 2001. Organic and conventional dairy farm comparisons in Ontario, Canada. Biol. Agric. Horticult. 19:115-125.

Tozer, P. R., F. Bargo, and L. D. Muller. 2003. Economic analyses of feeding systems combining pasture and total mixed ration. J. Dairy Sci. 86:808-818.

USDA Agricultural Marketing Service. 2010. National Organic Program (NOP) - Access to Pasture (Livestock). 7 CFR Part 205, Doc. No. AMS-TM-06-0198; TM-05-14FR. RIN 0581-AC57. US Department of Agriculture, Agricultural Marketing Service, Washington, DC.

USDA Economic Research Service. 2005. Agricultural Resources and Management Survey. US Department of Agriculture, Economic Research Service, Washington, DC.

USDA Economic Research Service. 2008. Monthly Organic Market Prices for Grain and Feedstuffs, 2007-08. US Department of Agriculture, Economic Research Service, Washington, DC.

USDA National Agricultural Statistics Service. 2010a. Quick Stats. US Department of Agriculture, National Agricultural Statistics Service, Washington, DC. Accessed August 10, 2010. http://www. nass.usda.gov/Data_and_Statistics/Quick_Stats_1.0/index.asp.

USDA National Agricultural Statistics Service. 2010b. 2007 Census of Agriculture: Organic Production Survey (2008). Volume 3, Special Studies, Part 2, AC-07-SS-2. US Department of Agriculture, National Agricultural Statistics Service, Washington, DC.

USDA Natural Resources Conservation Service. 2010a. Official Soil Series Descriptions. US Department of Agriculture, Natural Resources Conservation Service, Washington, DC. Accessed July 27, 2010. http://soils.usda.gov/technical/classification/osd/index.html.

USDA Natural Resources Conservation Service. 2010b. NRCS Web Soil Survey. US Department of Agriculture, Natural Resources Conservation Service, Washington, DC. Accessed July 27-28, 2010. websoilsurvey.nrcs.usda.gov/app/WebSoilSurvey.aspx.

Woodward, F. I. 1983. The significance of interspecific differences in specific leaf area to the growth of selected herbaceous species from different altitudes. New Phytol. 95:313-323. 